\title{
Histopathology of the Foot, Gill and Digestive Gland Tissues of Freshwater Mussel, Lamellidens marginalis Exposed to Oil Effluent
}

\author{
Balamurugan $\mathbf{S}^{1 *}$ and Subramanian $\mathbf{P}^{2}$ \\ ${ }^{1}$ Department of Zoology, Arignar Anna Government Arts \\ College, India \\ ${ }^{2}$ Department of Animal Science, Bharathidasan \\ University, India \\ *Corresponding author: Balamuirugan S, Department \\ of Zoology, Arignar Anna Government Arts College, \\ Musiri-621211, Tiruchirappalli-District, Tamilnadu, India
}

Received: December 04, 2020; Accepted: December 30, 2020; Published: J anuary 06, 2021

\begin{abstract}
We investigated the histopathological alterations in the tissues of freshwater mussel, Lamellidens marginalis in response to oil effluent. Based on the previous acute toxicity, two sub lethal $\left[1 / 4^{\text {th }}(11.88 \mathrm{ppt})\right.$ and $\left.1 / 10^{\text {th }}(8.55 \mathrm{ppt})\right]$ concentrations of oil effluent (hydrocarbon) were prepared and exposed to mussels. In a first series of experiment, animals were exposed/accumulated for 30 days $\left[I^{\text {st }}, 8^{\text {th }}, 15^{\text {th }}, 22^{\text {nd }}\right.$ and $30^{\text {th }}$ days] by two sub lethal concentrations of oil. In a second series of experiment, oil exposed animals were thereafter transferred to clean water and kept in it up to 30 days $\left[{ }^{\text {st }}, 8^{\text {th }}, 15^{\text {th }}, 22^{\text {nd }}\right.$ and $30^{\text {th }}$ days] to assess the recovery pattern (depuration). At seven-day intervals, histopathological alterations were analyzed in foot, gill and digestive gland tissues of mussel. First series of experimental observation showed remarkable damages in foot (disorganized outer epithelium, necrosis of the cell, the formation of lumina, disorganized muscle bundle); in gill (disruption of gill filaments, odema formation, necrosis, dis-aggregated cilia) and in digestive gland (stoma, detached glandular epithelium, vertical clefts, presence of leucocytes, dense accumulation of luminal material) and also oil effluent inducement are confirmed with the aforementioned results. At second series of experiment, it was found that oil effluent tended to accumulate in tissues in a duration-dose-dependent manner. Tissue burden by oil effluent of mussels completely were restored at $30^{\text {th }}$ day. The present experimental findings may be of early warning signals of oil effluent pollution. In conclusion oil effluent are highly toxic to the Lamellidens marginalis.
\end{abstract}

Keywords: Oil effluent; Accumulation and depuration; Histopathology of foot; Gill; Digestive gland; Lamellidens marginalis

\section{Abbreviations}

EP: Epithelium; MU: Muscle Tissue; CI: Cilia; NE: Nucleus; BS: Blood Sinus; MU: Muscle Tissue; NE: Necrosis of Epithelial Tissue; GF-Gill Filaments: CR: Chitinus Rod; FL: Frontal Lateral Cilia; FC: Frontal Cilia; IS: Interlamellar Space; IJ: Interlamellar Junction; WC: Water Chamber; MU: Muscle Tissue; SC: Supra Brachial Chamber; GF: Gill Filaments; FL: Frontal Lateral Cilia; DD: Digestive Diverticula; LU: Lumen; ST: Stomach

\section{Introduction}

Researchers with different expertise have converged towards a common interest for understanding and solving the problems associated with the occurrence of toxic level of contaminants in the environment, giving raise to the spectacular development of research in the field of Environmental Contamination and Toxicology, which has emerged as a multidisciplinary science resulting from the integration of classical disciplines such as toxicology, cell and molecular biology, physiology, ecology, chemistry, etc [1]. Uptake and accumulation of xenobiotics in the tissues of aquatic organisms occur from the sediment, contaminated water column and food chain [2] that cause deleterious effects. Incorporation of even very low levels of toxicants in the body of aquatic organisms causes various biochemical, physiological and hematological alterations in vital tissues [3]. Most common usage of the term biomarker has been for biochemical, physiological or histological indicators of their exposure to or the effects of xenobiotic chemicals at the sub-organismal or organismal level [4]. Most of the monitoring programmes are confined to the chemical analysis of accumulated substances, but sometimes include toxic responses, for instance histopathological effects $[5,6]$ or physiological/biochemical responses [7]. When Polycyclic Aromatic Hydrocarbon (PAHs) exposed animals, several deleterious effects such as DNA damage [8]. As an indicator of exposure to contaminant, histology represents a useful tool to assess the degree of pollution, particularly for sub lethal and chronic effects [9]. Histological changes appear as a medium-term response to sub-lethal stressors, and histology provides a rapid method to detect effects tissues and organs [10]. Summary of some relevant earlier literature on marine as well as freshwater mussels histopathological observations with various toxicant exposure results are compiled (Table 1). In molluscs, especially in Lamellidens marginalis histological injuries, in response to the exposure to oil effluent, remains unexplored. Gills are the vital organs, which come into direct contact with water and are indicative of any environmental stress and also in fishes gills are the major vital respiratory organs [11]. The numerous lamellae along the double row of filament attached to the gill arch are affected by toxicants 
Table 1: Summary of Relevant Earlier Literatures on Freshwater and Marine Mussels Histolagical Changes with Various Xenobiotic Exposures and Comparison with Our Results.

\begin{tabular}{|c|c|c|c|c|c|}
\hline Marine Mussels & Pollutants & Tissues & Responses/Effect & Year & Reference \\
\hline $\begin{array}{l}\text { Mytilus } \\
\text { galloprovincialis }\end{array}$ & Metals & Gill, digestive gland & brown cells, metal burden in tissues & 1997 & {$[42]$} \\
\hline Perna indica & Heavy metals & Gill, digestive galnd & $\begin{array}{l}\text { Clumping of ciliary, damage of gill filaments, dislodged } \\
\text { epithelial cells, disintegration of digestive tubules }\end{array}$ & 2005 & {$[46]$} \\
\hline $\begin{array}{l}\text { Crenomytilus } \\
\text { grayanus }\end{array}$ & Heavy metals and pesticides & Digestive gland & $\begin{array}{l}\text { Heavy vacuolization of digestive cells, desquamation } \\
\text { of digestive cells of tubules, necrosis, Edemata, lysis of } \\
\text { vesicular cells and of muscle fifibers }\end{array}$ & 2006 & {$[17]$} \\
\hline Perna viridis & Heavy metals & Gill & $\begin{array}{l}\text { Loss of cilia, epithelial cell damage, swollen lumen, } \\
\text { elongation of gill filaments. }\end{array}$ & 2008 & {$[40]$} \\
\hline Mytilus edulis & Heavy metal & $\begin{array}{l}\text { Gill, Digestive gland } \\
\text { and adductor muscle }\end{array}$ & Inflammation and necrosis. & 2010 & {$[44]$} \\
\hline $\begin{array}{l}\text { Gafrarium } \\
\text { divaricatum (clams) }\end{array}$ & xylene, benzene and gear oil-WSF & Hepatopancreas & $\begin{array}{l}\text { Cell debris, fusion of Nuclei, interruption of lumen line, } \\
\text { disintegration of epithelial cells, necrosis, iated epithelial } \\
\text { layer, detachment of epithelial cells. }\end{array}$ & 2011 & [53] \\
\hline Perna viridis & Heavy metal & $\begin{array}{l}\text { Gill, Digestive gland } \\
\text { and adductor muscle }\end{array}$ & $\begin{array}{l}\text { digestive epithelium, hemocytic infiltration in the gills } \\
\text { and myodegeneration in the muscle tissue, necrosis } \\
\text { and digestive tubule thickness }\end{array}$ & 2012 & [45] \\
\hline $\begin{array}{l}\text { Mytilus } \\
\text { galloprovincialis }\end{array}$ & PAH & Digestive gland & Altered diverticula, damages in digestive tubule & 2013 & [47] \\
\hline $\begin{array}{l}\text { Ruditapes } \\
\text { decussatus }\end{array}$ & Anthropogenic activities & Gill ,Digestive gland & $\begin{array}{l}\text { intertubular tissue necrosis, lesions such as digestive } \\
\text { tubule (diverticula) }\end{array}$ & 2013 & [52] \\
\hline $\begin{array}{l}\text { Mytilus } \\
\text { galloprovincialis }\end{array}$ & $\begin{array}{l}\text { Industry Effluent (Iron, paper } \\
\text { Harbour, cement etc.,) }\end{array}$ & Gill, Hepatopancreas & $\begin{array}{l}\text { dejeneration, cell loss and necrose, lumen enlargement, } \\
\text { Cilia loss and fusion, haemocytic infiltration, vacuolar } \\
\text { degeneration }\end{array}$ & 2016 & [48] \\
\hline $\begin{array}{l}\text { Mytilus } \\
\text { galloprovincialis }\end{array}$ & Cadmium & Digestive gland & $\begin{array}{l}\text { lumen of digestive tubules, increase of the atrophic } \\
\text { tubule }\end{array}$ & 2016 & [51] \\
\hline Mytilus spp. & Mixture of Microplastics & Gill, Digestive gland & Necrosis, atrophies, lumen enlargement & 2019 & [39] \\
\hline $\begin{array}{l}\text { Mytilus } \\
\text { galloprovincialis }\end{array}$ & Insecticide & Gill, Digestive gland & $\begin{array}{l}\text { Vacuolation, epithelial alterations, lipofuscin aggregates, } \\
\text { presence of brown cells, digestive tubule alterations, } \\
\text { hypertrophy, hyperplasia. }\end{array}$ & 2020 & [36] \\
\hline \multicolumn{6}{|l|}{ Freshwater Mussel } \\
\hline $\begin{array}{l}\text { Lamellidens } \\
\text { marginalis }\end{array}$ & Oil effluent (hydrocarbon) & $\begin{array}{l}\text { Foot, Gill, Digestive } \\
\text { gland }\end{array}$ & $\begin{array}{l}\text { Foot-disorganization ofouter epithelium, necrosis of } \\
\text { the cell, formation of lumina, disorganisation of muscle } \\
\text { bundle, Gill-disruption of the epithelium, oedima } \\
\text { formation and necrosis, cilia appeared disaggregated } \\
\text { Digestive gland- stroma, detached glandular epithelium, } \\
\text { dense accumulation leucocytes, integrity of the } \\
\text { epithelium, vertical clefts. }\end{array}$ & 2020 & *Our Results \\
\hline $\begin{array}{l}\text { Lamellidens } \\
\text { marginalis }\end{array}$ & Heavy metals & Foot, Hepatopancreas & $\begin{array}{l}\text { splitting of muscle bundles, loss of connective tissue, } \\
\text { oedema, atrophy of muscle bundles, Cell necrosis, } \\
\text { damage to the intertubular connective tissue }\end{array}$ & 2008 & [26] \\
\hline $\begin{array}{l}\text { Lamellidens } \\
\text { marginalis }\end{array}$ & Insecticide & Gill & $\begin{array}{l}\text { The bulging of primary filament gill tips, curling of } \\
\text { secondary filament, fusion of gill lamellae, hyperplasia, } \\
\text { necrotic and clavate globate lamellae of the gills }\end{array}$ & 2011 & [33] \\
\hline $\begin{array}{l}\text { Lamellidens } \\
\text { marginalis }\end{array}$ & Dimethoate & Hepatopancreas & $\begin{array}{l}\text { Distruption in digestive tubules, disrupted epithelial } \\
\text { lining and necrotic tissue in the lumen, Hypertrophic } \\
\text { nucleus, Necrotic tissue }\end{array}$ & 2011 & {$[54]$} \\
\hline $\begin{array}{l}\text { Lamellidens } \\
\text { marginalis }\end{array}$ & Dimethoate & Gill & $\begin{array}{l}\text { Disruption in epithelium, damage in epithelial lining, } \\
\text { nuclear hypertrophy etc. }\end{array}$ & 2012 & [34] \\
\hline $\begin{array}{l}\text { Lamellidens } \\
\text { marginalis }\end{array}$ & Pesticide & Gill, Digestive gland & $\begin{array}{l}\text { gill exhibiting reduced space between water channel } \\
\text { and interlamellar junction, intense infiltration of hyper } \\
\text { chromatic anaplastic cells, tissue swelling ,irregular } \\
\text { shaped branchial filaments, digestive gland exhibiting } \\
\text { hepatic tubules with disintegrated epithelial cells and } \\
\text { infiltrated basophilic cells }\end{array}$ & 2012 & [35] \\
\hline $\begin{array}{l}\text { Dreissena } \\
\text { polymorpha }\end{array}$ & Fluoride & Gill, Digestive gland & $\begin{array}{l}\text { scattered pyknotic nuclei, condensed nuclei, altered } \\
\text { morphology of the cells }\end{array}$ & 2012 & [50] \\
\hline $\begin{array}{l}\text { Lamellidens } \\
\text { marginalis }\end{array}$ & Monocrotophos & Foot & $\begin{array}{l}\text { Hyperplasia of marginal pedal glands, distruption of } \\
\text { nuclei of the epithelial glands. }\end{array}$ & 2015 & [27] \\
\hline $\begin{array}{l}\text { Lamellidens } \\
\text { marginalis }\end{array}$ & Mercury choloride & Gill & $\begin{array}{l}\text { Hypoplasia of epithelial cells, gill filaments altered, } \\
\text { oedematic, necrotic and vacuolated epithelium }\end{array}$ & 2016 & [41] \\
\hline Anodonta cygnea & Heavy metals & $\begin{array}{l}\text { Gill, digestive gland } \\
\text { and gonads }\end{array}$ & $\begin{array}{l}\text { Gills-lamellar fusion, dilated hemolymphatic sinus, } \\
\text { clumping, and generation of cilia and hemocytic } \\
\text { infiltration digestive gland-inflammation, hydropic } \\
\text { vacuolation, and lipofuscin pigments, and gonads- } \\
\text { atresia, necrosis, granulocytoma, hemocytic infiltration }\end{array}$ & 2018 & [49] \\
\hline Unio Pictorum & Pesticide & Gill & damaged cilia, epithelium rupture, damaged epithelium & 2019 & {$[37]$} \\
\hline $\begin{array}{l}\text { Lamellidens } \\
\text { marginalis }\end{array}$ & Pesticide & Gill & $\begin{array}{l}\text { Damaged ciliated epithelium, Elongated gill filament, } \\
\text { Delaminated ciliated epithelium, gill epithelium ruptured } \\
\text { with damaged ciliary lining }\end{array}$ & 2019 & [38] \\
\hline
\end{tabular}


[12]. Molluscs are widely used in different biomonitoring projects and their histopathological analysis provides information about the general health of the animals and contaminant-specific changes in the tissues. Although laboratory as well as field studies suggest that pollutants cause toxic effects to molluscs, the histopathological effects of chemical contaminants have not generally been measured [13]. Blue mussels can retain on their gills, including oil particles have observed [14]. Like numerous bivalves, they concentrate many xenobiotics in their tissues and have been used extensively for biomonitoring of pollutants [15] but there is inadequate contribution on freshwater mussels. Gills [16] are suitable organs for histological examination in order to determine the effect of pollution. Histological changes occurs in the bivalves especially in the hepatopancreas (digestive gland) as they are the metabolically active sites and are responsible for food collection, absorption, digestion, enzymatic activity as well as accumulation and biotransformation (detoxification) of various organic and inorganic toxic substances upon exposure to the organic and inorganic contaminants in the water. Pathological changes in the vital tissues of bivalves have been reported after pollutant exposure $[17,6]$. Owing to their poor existence and meagre information about the histopathology in invertebrates remarkably in freshwater mussels. This present study attempts to understand the pathological injuries in mussels. Therefore, present investigation were examined during acumulation (30 days) and depuration (recovery) period (30 days) in response to sub lethal concentration of $1 / 4^{\text {th }}(11.88 \mathrm{ppt})$ and $1 / 10^{\text {th }}$ (8.55ppt) of oil effluent in freshwater mussel tissues of foot, gill and digestive gland. The aims of present study were to observe (1) histopathological damages in foot, gill and digestive gland tissues of mussels during accumulation period of both sublethal concentrations of oil effluent in comparison to control (2) whether these histopathological damages in various tissues of mussels recoverd/ restored in the depuration period in comparison to control mussels and (3) whether these alteration/damages would serve as a biomarker to detect the accumulated oil effluent (hydrocarbon) in this species.

\section{Materials and Methods}

\section{Animals}

Almost uniform size fresh water mussel Lamellidens marginalis (total length 6-7 cm and weight 25-27 g) were collected from the River Cauvery (Tiruchirappalli, India) and maintained in the laboratory.

\section{Acute toxicity experiment}

The aqueous oil effluent originated from the coal conversion plant, turbine section of boiler units in the Boiler plants of Bharat Heavy Electricals Limited (BHEL) situated $14 \mathrm{~km}$ away from Tiruchirappalli, are collectively released into a drainage canal. It consisted mainly of hydrocarbons. Initial experiments were conducted to assess the minimum concentration of oil effluent to obtain maximum mortality, for freshwater mussel, Lamellidens marginalis, over a 96-hr exposure. After confirming the minimum concentration, 10 animals in $5 \mathrm{~L}$ of tubs (each) and exposed to various concentrations of oil effluent, ranging from $4 \mathrm{ppt}$ to $16 \mathrm{ppt}$ for a period of $96-\mathrm{hr}$ to ascertain LC50 concentration. In addition, a control was also maintained. The 96hr LC50 values with 95\% confidence limits were calculated using National Crop Production Centre Technical Bulletin [18].

\section{Exposure experiment}

Based on the 96-hr LC50 value of oil effluent, sublethal concentrations of $1 / 4^{\text {th }}(11.88 \mathrm{ppt})$ and $1 / 10^{\text {th }}(8.55 \mathrm{ppt})$ of LC50 were prepared and used for histopathology. In this study, two sets of 10-1 plastic tubs were used. In each tub, mussels were exposed to 11.88ppt or $8.55 \mathrm{ppt}$ of oil effluent. A control was also run simultaneously without the addition of oil effluent. At seven days interval, mussels were sacrificed for histological analysis. After 30 days, the treated mussels were released into freshwater 30-day depuration (recovery) study was conducted. Four mussels were randomly chosen and removed from each of the two tubs $(n=8)$ for dissection.

\section{Preparations of tissue samples}

Control set of animals tissues were sacrificed for $I^{\text {st }}, 8^{\text {th }}, 15^{\text {th }}, 22^{\text {nd }}$ and $30^{\text {th }}$ days of foot, gill and digestive gland tissues of mussels. At every seven days intervals, accumulation and depuration (recovery) period of $I^{\text {st }}, 8^{\text {th }}, 15^{\text {th }}, 22^{\text {nd }}$ and $30^{\text {th }}$ days of foot, gill and digestive gland tissues of mussels from both exposures were sacrificed for the evaluation of histological analysis.

Paraffin method: For the paraffin method, the above specified tissues were fixed in Bouin's fluid, and embedded in paraffin. Serial sections were obtained at 3-5 $\mu \mathrm{m}$ thickness using a Leica (Germany) microtome with provision of disposable blade. Serial sections stained in haematoxylin and eosin [19] and mounted in DPX mountant for microscopical observations.

Microscopic analysis: For light microscopic observation CarlZeiss (Germany) Axioskop 2-research microscope was used, and the images were captured in a computer using Carl-Zeiss (Germany) Axiovision Software and the images processed using the same software. The histopathological changes in the tissues of experimental as well as control mussels were recorded and compared.

\section{Results}

\section{Histology of foot}

Foot is the locomotory organ chiefly employed for burrowing and is formed of an outer dense epithelium, which is grown into tall folds (villous); the epithelium lies top of the cells the musculature, variety of protractor, retractor muscles. Blood sinuses are found between the fine muscles. The muscular wall of the foot surrounds the coelomic phase which itself is lined by coelomic epithelium. In the outer epithelium, the cells differ in height and length of the nucleus. In some of the cells the nucleus is extremely elongated. The outer borders of the epithelium have dense cilia (Figures 1-4).

\section{Histopathology of foot}

During the exposure of both sublethal concentrations $\left(1 / 4^{\text {th }}\right.$ and $\left.1 / 10^{\text {th }}\right)$ of oil effluent little changes were observed in the foot tissues of mussel at It day. However, from the $8^{\text {th }}$ day onwards the outer

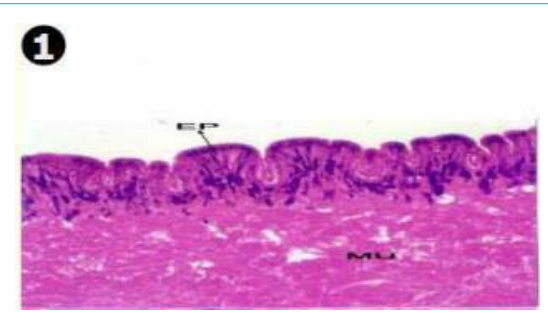

Figure 1: Haematoxylin and eosin stained paraffin sections of control mussel Lamellidens marginalis foot tissue. (X100, 400). 


\section{(2)}

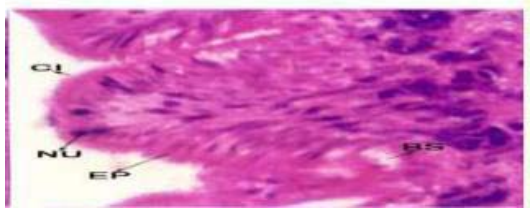

Figure 2: Haematoxylin and eosin stained paraffin sections of control mussel Lamellidens marginalis foot tissue. (X100, 400).

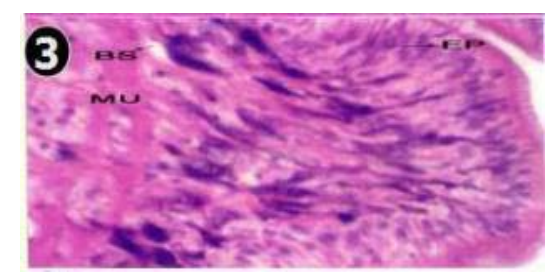

Figure 3: Haematoxylin and eosin stained paraffin sections of treated mussel $\left(1 / 4^{\text {th }}\right.$ accumulation- $1^{\text {st }}, 8^{\text {th }}$ and $15^{\text {th }}$ days) foot tissue. (X400).

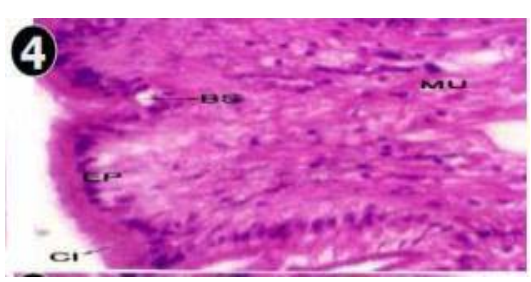

Figure 4: Haematoxylin and eosin stained paraffin sections of treated mussel $\left(1 / 4^{\text {th }}\right.$ accumulation- $\left.\right|^{\text {st }}, 8^{\text {th }}$ and $15^{\text {th }}$ days) foot tissue. (X400).

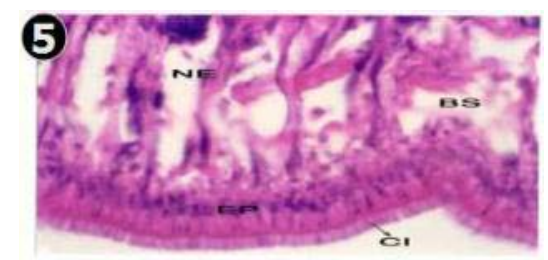

Figure 5: Haematoxylin and eosin stained paraffin sections of treated mussel $\left(1 / 4^{\text {th }}\right.$ accumulation- $\left.\right|^{\text {st }}, 8^{\text {th }}$ and $15^{\text {th }}$ days) foot tissue. (X400).

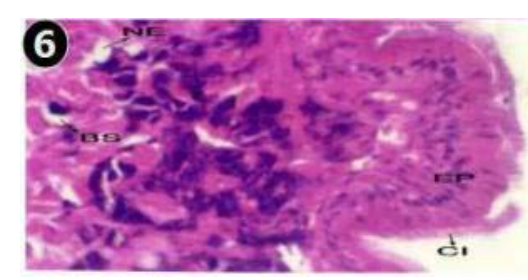

Figure 6: Haematoxylin and eosin stained paraffin sections of treated mussel $\left(1 / 4^{\text {th }}\right.$ accumulation- $\left.\right|^{\text {st }}, 8^{\text {th }}$ and $15^{\text {th }}$ days) foot tissue. (X400).

epithelium was thoroughly disorganized resulted in necrosis of the cell and formation of lumina both on top of the musculature, with exposure for longer durations the muscle bundle themselves were disorganized in both sublethal concentration of oil effluent exposure (Figures 5-11). During the depuration (recovery) process, the fresh water mussel brought about almost complete restorations of the

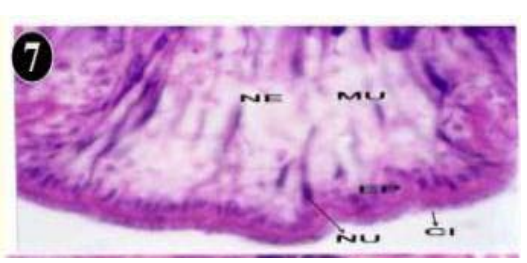

Figure 7: Haematoxylin and eosin stained paraffin sections of treated musse $\left(1 / 4^{\text {th }}\right.$ accumulation- $22^{\text {nd }}$ and $30^{\text {th }}$ days) foot tissue. (X400).

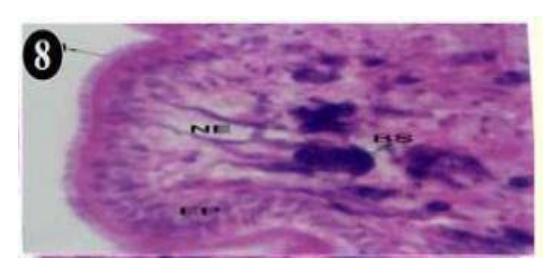

Figure 8: Haematoxylin and eosin stained paraffin sections of treated mussel $\left(1 / 4^{\text {th }}\right.$ accumulation- $22^{\text {nd }}$ and $30^{\text {th }}$ days) foot tissue. (X400).

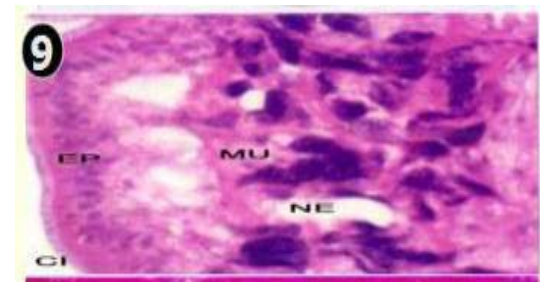

Figure 9: Haematoxylin and eosin stained paraffin sections of treated mussel $\left(1 / 10^{\text {th }}\right.$ accumulation- $8^{\text {th }}, 15^{\text {th }}$ and $22^{\text {nd }}$ days) foot tissue. (X400, X400, X100).

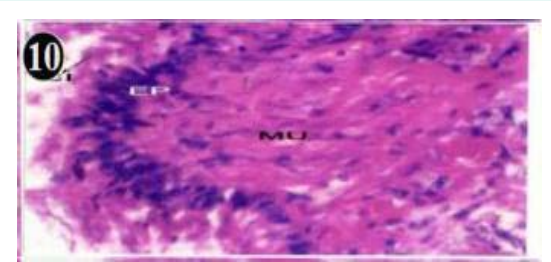

Figure 10: Haematoxylin and eosin stained paraffin sections of treated mussel $\left(1 / 10^{\text {th }}\right.$ accumulation- $8^{\text {th }}, 15^{\text {th }}$ and $22^{\text {nd }}$ days) foot tissue. (X400, X400, $\mathrm{X} 100)$.

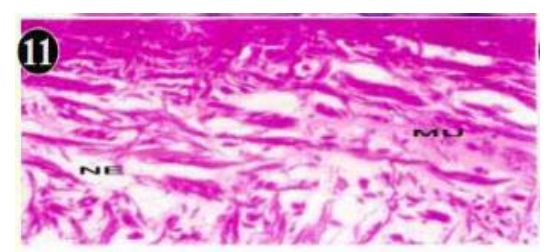

Figure 11: Haematoxylin and eosin stained paraffin sections of treated mussel $\left(1 / 10^{\text {th }}\right.$ accumulation- $8^{\text {th }}, 15$ and $22^{\text {nd }}$ days) foot tissue. (X400, X400 X100).

histo-architecture of the foot tissues (Figures 12-21).

\section{Histology of gill}

The gill of the mussel is formed of an outer and inner lamellae called ctenidium, each folded to form the outer and inner lamellae. The lamellae are connected by inter-lamellar junctions, which contain blood vessels. The gill filament constitutes a longitudinal array and 


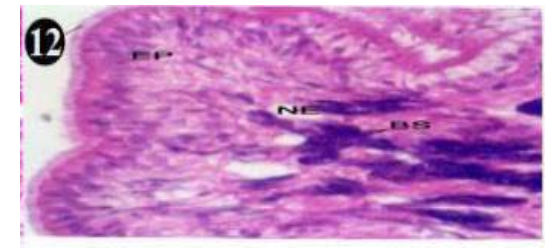

Figure 12: Haematoxylin and eosin stained paraffin sections during depuration period of mussel $\left(1 / 4^{\text {th }}\right.$ depuration- ${ }^{\text {st }}$ day) foot tissue. (X400)

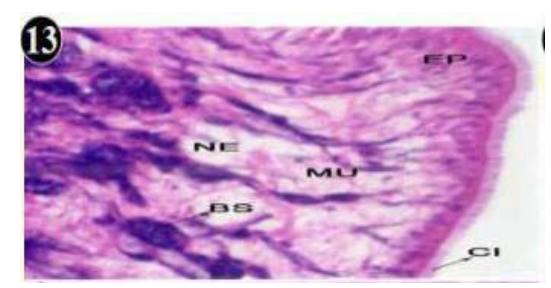

Figure 13: Haematoxylin and eosin stained paraffin sections during depuration period of mussel $\left(1 / 4^{\text {th }}\right.$ depuration- $8^{\text {th }}, 15^{\text {th }}, 22^{\text {nd }}$ and $30^{\text {th }}$ days) foot tissues. (X400, X1000).

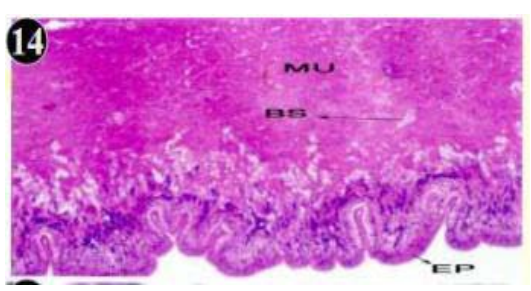

Figure 14: Haematoxylin and eosin stained paraffin sections during depuration period of mussel $\left(1 / 4^{\text {th }}\right.$ depuration- $8^{\text {th }}, 15^{\text {th }}, 22^{\text {nd }}$ and $30^{\text {th }}$ days $)$ foot tissues. (X400, X1000)

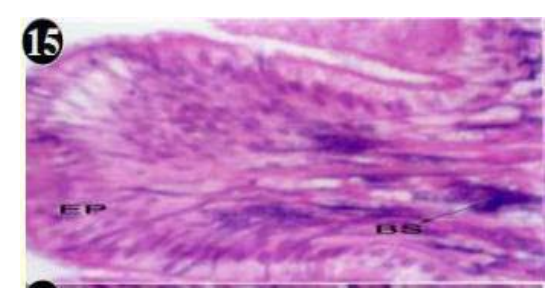

Figure 15: Haematoxylin and eosin stained paraffin sections during depuration period of mussel $\left(1 / 4^{\text {th }}\right.$ depuration- $8^{\text {th }}, 15^{\text {th }}, 22^{\text {nd }}$ and $30^{\text {th }}$ days $)$ foot tissues. (X400, X1000).

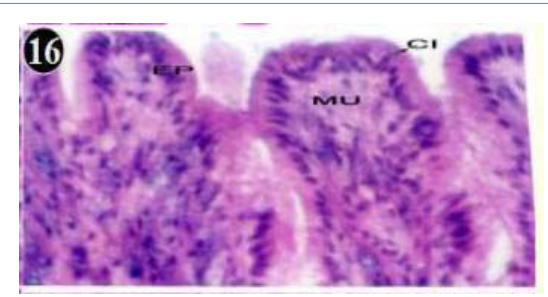

Figure 16: Haematoxylin and eosin stained paraffin sections during depuration period of mussel $\left(1 / 4^{\text {th }}\right.$ depuration- $8^{\text {th }}, 15^{\text {th }}, 22^{\text {nd }}$ and $30^{\text {th }}$ days $)$ foot tissues. (X400, X1000).

adjacent filaments are connected by inter-filamentor junctions. The gill filament is lined by an epithelium formed of a single row cells, short cuboidal adiphase and tall columnar towards the tip. Three

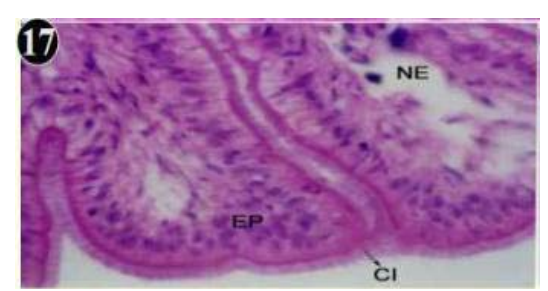

Figure 17: Haematoxylin and eosin stained paraffin sections during depuration period of mussel $\left(1 / 10^{\text {th }}\right.$ depuration- $\left.\right|^{\text {st }}$ and $8^{\text {th }}$ days $)$ foot tissues. (X400).

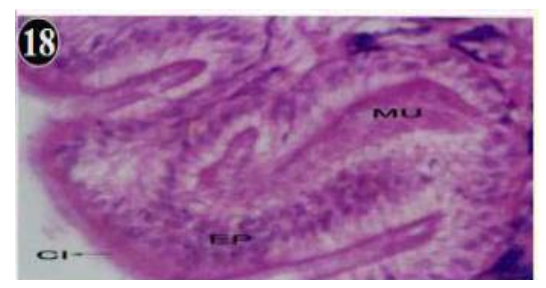

Figure 18: Haematoxylin and eosin stained paraffin sections during depuration period of mussel $\left(1 / 10^{\text {th }}\right.$ depuration- It $^{\text {st }}$ and $8^{\text {th }}$ days $)$ foot tissues. (X400).

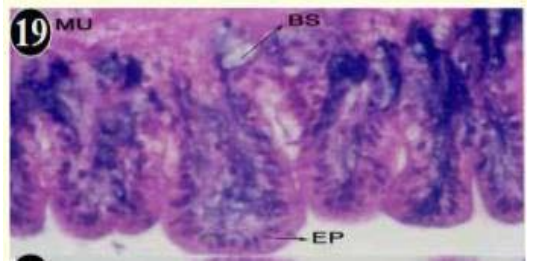

Figure 19: Haematoxylin and eosin stained paraffin sections during depuration period of mussel $\left(1 / 10^{\text {th }}\right.$ depuration- $\left.\right|^{\text {st }}$ and $8^{\text {th }}$ days $)$ foot tissues. (X100, X400).

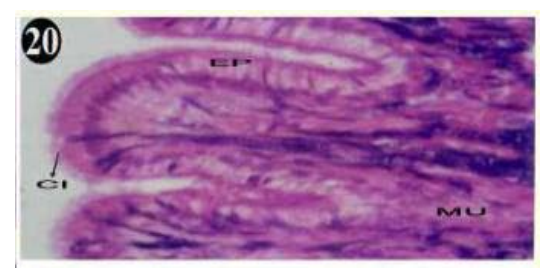

Figure 20: Haematoxylin and eosin stained paraffin sections during depuration period of mussel $\left(1 / 10^{\text {th }}\right.$ depuration- $15^{\text {th }}, 22^{\text {nd }}$ and $30^{\text {th }}$ days $)$ foot tissues. (X100, X400).

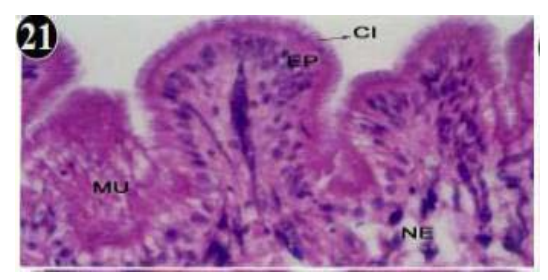

Figure 21: Haematoxylin and eosin stained paraffin sections during depuration period of mussel $\left(1 / 10^{\text {th }}\right.$ depuration- $15^{\text {th }}, 22^{\text {nd }}$ and $30^{\text {th }}$ days) foot tissues. (X100, X400).

types of cilia are associated with gill filament, they are, tall lateral-cilia, tall latero-frontal cilia and short frontal -cilia at the tip. The stroma underlying the epithelium bridges of connective tissue containing 


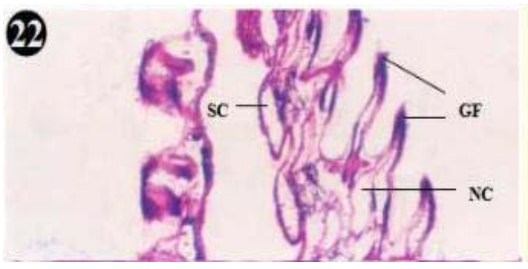

Figure 22: Haematoxylin and eosin stained paraffin sections of control mussel gill tissues (X400, X1000).

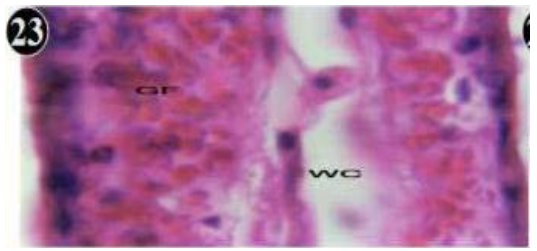

Figure 23: Haematoxylin and eosin stained paraffin sections of control mussel gill tissues (X400, X1000).

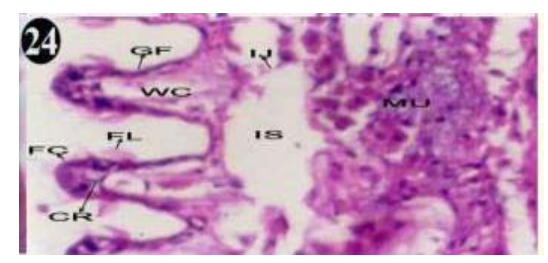

Figure 24: Haematoxylin and eosin stained paraffin sections of treated mussel gill tissues $\left(1 / 4^{\text {th }}\right.$ accumulation- $1^{\text {st }}$ day) $(X 400)$.

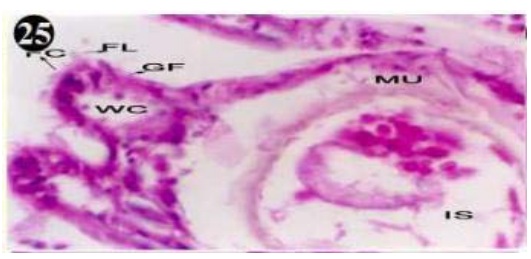

Figure 25: Haematoxylin and eosin stained paraffin sections of treated mussel gill tissues $\left(1 / 4^{\text {th }}\right.$ accumulation- $8^{\text {th }}, 15^{\text {th }}, 22^{\text {nd }}$ and $30^{\text {th }}$ days and $1 / 10^{\text {th }}$ accumulation- $\left.\right|^{\text {st }}$ day and $8^{\text {th }}$ day). (X400).

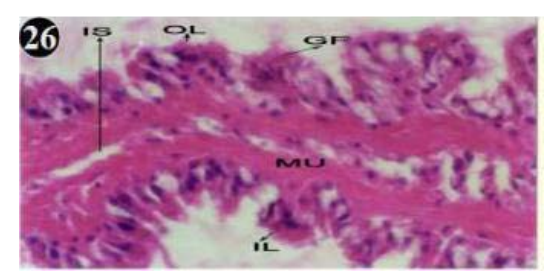

Figure 26: Haematoxylin and eosin stained paraffin sections of treated mussel gill tissues $\left(1 / 4^{\text {th }}\right.$ accumulation- $8^{\text {th }}, 15^{\text {th }}, 22^{\text {nd }}$ and $30^{\text {th }}$ days and $1 / 10^{\text {th }}$ accumulation- $-^{\text {st }}$ day and $8^{\text {th }}$ day). (X400).

connecting rods for support and also blood vessels (Figures 22,23).

\section{Histopathology of gill}

When exposed to both sublethal concentrations of oil effluent caused disruption of the epithelium of the gill filaments and all the versions of the cilia. The epithelium indicated severe pathological changes of the oedima formation and necrosis. Disaggregated cilia

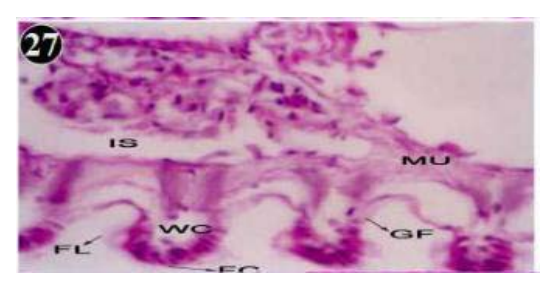

Figure 27: Haematoxylin and eosin stained paraffin sections of treated mussel gill tissues $\left(1 / 4^{\text {th }}\right.$ accumulation- $8^{\text {th }}, 15^{\text {th }}, 22^{\text {nd }}$ and $30^{\text {th }}$ days and $1 / 10^{\text {th }}$ accumulation-Ist day and $8^{\text {th }}$ day). (X400).

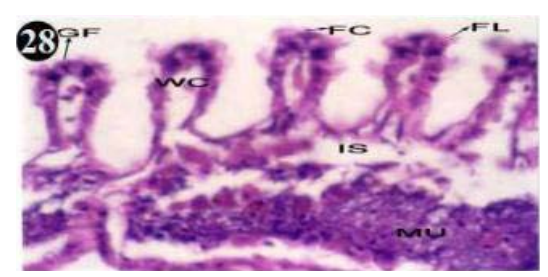

Figure 28: Haematoxylin and eosin stained paraffin sections of treated mussel gill tissues $\left(1 / 4^{\text {th }}\right.$ accumulation- $8^{\text {th }}, 15^{\text {th }}, 22^{\text {th }}$ and $30^{\text {th }}$ days and $1 / 10^{\text {th }}$ accumulation- $\left.\right|^{\text {st }}$ day and $8^{\text {th }}$ day). (X400).

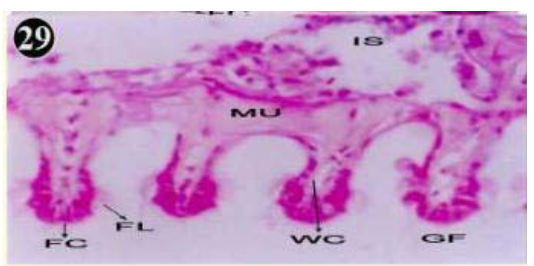

Figure 29: Haematoxylin and eosin stained paraffin sections of treated mussel gill tissues $\left(1 / 4^{\text {th }}\right.$ accumulation- $8^{\text {th }}, 15^{\text {th }}, 22^{\text {nd }}$ and $30^{\text {th }}$ days and $1 / 10^{\text {th }}$ accumulation- $\left.\right|^{\text {st }}$ day and $8^{\text {th }}$ day). (X400).

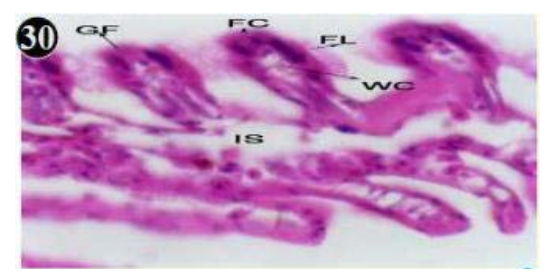

Figure 30: Haematoxylin and eosin stained paraffin sections of treated mussel gill tissues $\left(1 / 4^{\text {th }}\right.$ accumulation- $8^{\text {th }}, 15^{\text {th }}, 22^{\text {nd }}$ and $30^{\text {th }}$ days and $1 / 10^{\text {th }}$ accumulation- $I^{\text {st }}$ day and $8^{\text {th }}$ day). (X400).

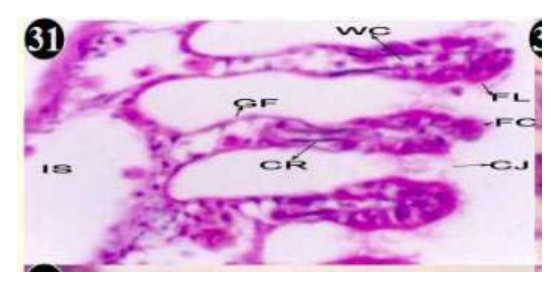

Figure 31: Haematoxylin and eosin stained paraffin sections of treated mussel gill tissues (1/10 th accumulation-22 $2^{\text {nd }}$ and $30^{\text {th }}$ days). (X400).

were appeared (Figures 24-32). During the recovery period, brought about partial to almost complete restoration of the histo-architecture of the gill filaments. The cilia appeared normal. The epithelium shows almost free from oedima formation and necrosis (Figures 33-42). 


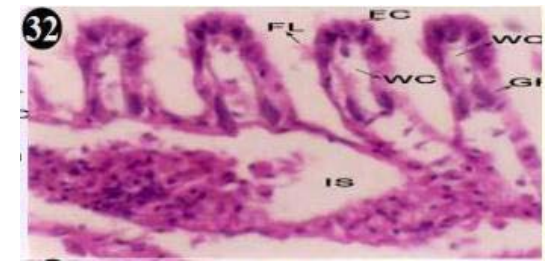

Figure 32: Haematoxylin and eosin stained paraffin sections of treated mussel gill tissues $\left(1 / 10^{\text {th }}\right.$ accumulation-22 $2^{\text {nd }}$ and $30^{\text {th }}$ days). (X400).

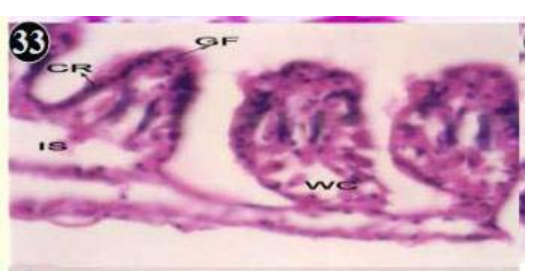

Figure 33: Haematoxylin and eosin stained paraffin sections during depuration period of mussel gill tissues $\left(1 / 4^{\text {th }}\right.$ depuration-I $\left.\right|^{\text {st }}, 8^{\text {th }}, 15^{\text {th }}, 22^{\text {nd }}$ days). (X400).

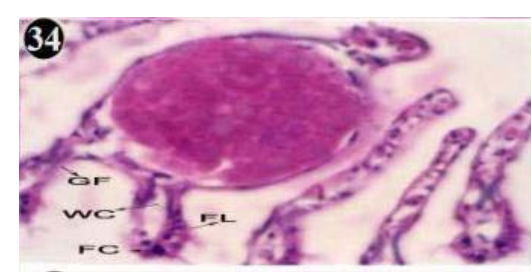

Figure 34: Haematoxylin and eosin stained paraffin sections during depuration period of mussel gill tissues $\left(1 / 4^{\text {th }}\right.$ depuration- $\left.\right|^{\text {st }}, 8^{\text {th }}, 15^{\text {th }}, 22^{\text {nd }}$ days). (X400).

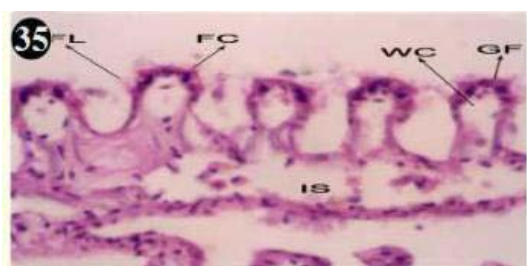

Figure 35: Haematoxylin and eosin stained paraffin sections during depuration period of mussel gill tissues $\left(1 / 4^{\text {th }}\right.$ depuration- $\left.\right|^{\text {st }}, 8^{\text {th }}, 15^{\text {th }}, 22^{\text {nd }}$ days). (X400).

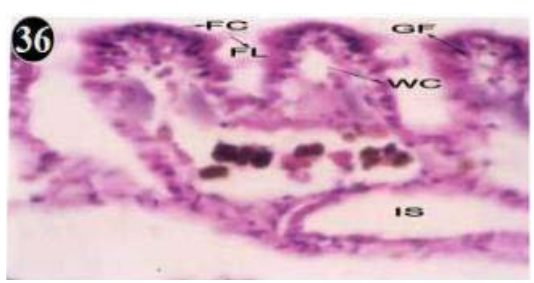

Figure 36: Haematoxylin and eosin stained paraffin sections during depuration period of mussel gill tissues $\left(1 / 4^{\text {th }}\right.$ depuration- $\left.\right|^{\text {st }}, 8^{\text {th }}, 15^{\text {th }}, 22^{\text {nd }}$ days). (X400).

\section{Histology of digestive gland}

The digestive gland consists of diverticula and their ducts, which connected to be, and inter diverticula tissue (Figure 43). The

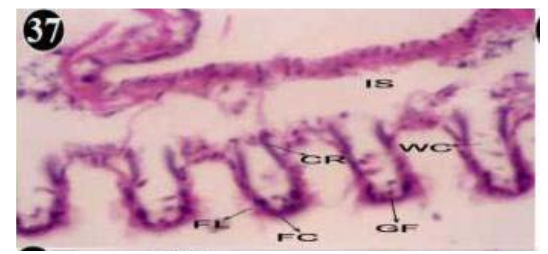

Figure 37: Haematoxylin and eosin stained paraffin sections during depuration period of mussel gill tissues ( $1 / 4^{\text {th }}$ depuration- $30^{\text {th }}$ days). (X400).

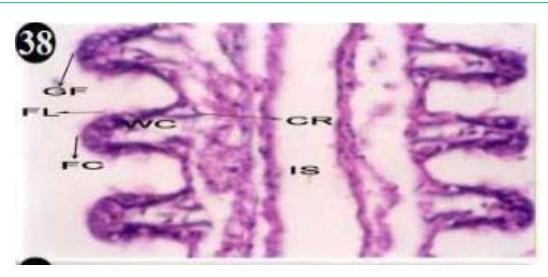

Figure 38: Haematoxylin and eosin stained paraffin sections during depuration period of mussel gill tissues $\left(1 / 10^{\text {th }}\right.$ depuration- $-^{\text {st }}, 8^{\text {th }}, 15^{\text {th }}, 22^{\text {nd }}$ and $30^{\text {th }}$ days). (X400).

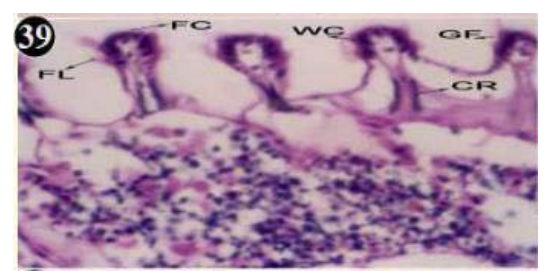

Figure 39: Haematoxylin and eosin stained paraffin sections during depuration period of mussel gill tissues $\left(1 / 10^{\text {th }}\right.$ depuration- $\left.\right|^{\text {st }}, 8^{\text {th }}, 15^{\text {th }}, 22^{\text {nd }}$ and $30^{\text {th }}$ days). (X400).

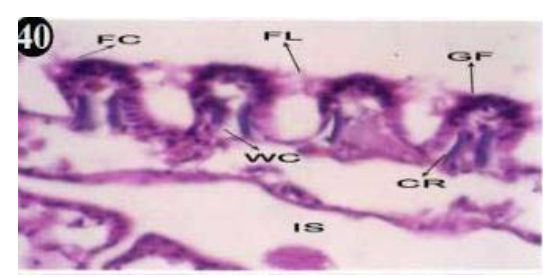

Figure 40: Haematoxylin and eosin stained paraffin sections during depuration period of mussel gill tissues $\left(1 / 10^{\text {th }}\right.$ depuration- $\left.\right|^{\text {st }}, 8^{\text {th }}, 15^{\text {th }}, 22^{\text {nd }}$ and $30^{\text {th }}$ days). (X400).

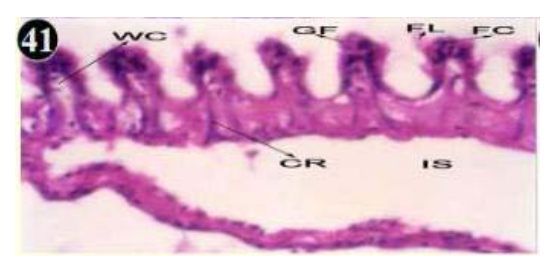

Figure 41: Haematoxylin and eosin stained paraffin sections during depuration period of mussel gill tissues $\left(1 / 10^{\text {th }}\right.$ depuration- $\left.\right|^{\text {st }}, 8^{\text {th }}, 15^{\text {th }}, 22^{\text {nd }}$ and $30^{\text {th }}$ days). (X400).

glandular epithelium is formed of different types, most of which are tall columnar. The different heights of the cell, render the epithelium appears live villous folds, lamellae propitious underlies the epithelium. The lumen of diverticulate contains a few materials, which are likely the ingested food (Figure 44). The nucleus of epithelium is elongated, 


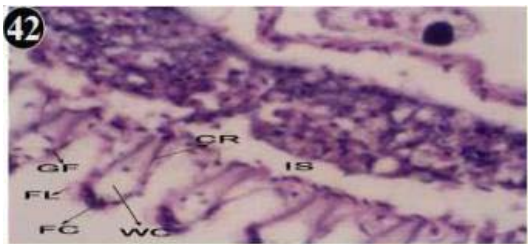

Figure 42: Haematoxylin and eosin stained paraffin sections during depuration period of mussel gill tissues $\left(1 / 10^{\text {th }}\right.$ depuration- $I^{\text {st }}, 8^{\text {th }}, 15^{\text {th }}, 22^{\text {nd }}$ and $30^{\text {th }}$ days). (X400).

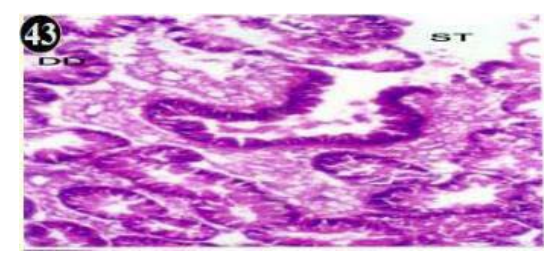

Figure 43: Haematoxylin and eosin stained paraffin sections of control mussel Lamellidens marginalis digestive gland tissue. (X100, X400, X100)

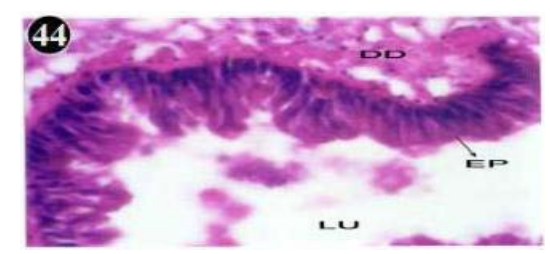

Figure 44: Haematoxylin and eosin stained paraffin sections of contro mussel Lamellidens marginalis digestive gland tissue. (X100, X400, X100).

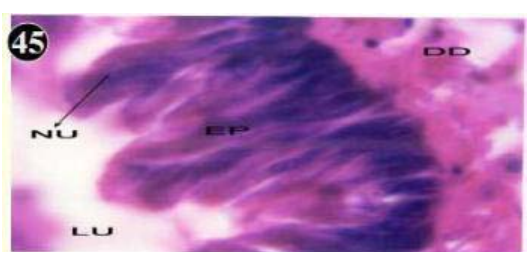

Figure 45: Haematoxylin and eosin stained paraffin sections of contro mussel Lamellidens marginalis digestive gland tissue. (X100, X400, X100).

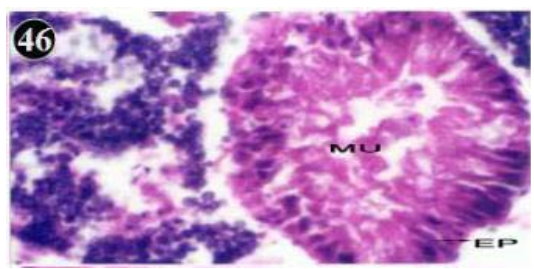

Figure 46: Haematoxylin and eosin stained paraffin sections of treated mussel digestive gland tissue. (1/4 $4^{\text {th }}$ accumulation- $I^{\text {st }}, 8^{\text {th }}$ and $15^{\text {th }}$ days) (X400).

spindle shaped and darkly staining, it is located at different heights of the cells. The folds of epithelium produce pockets in the profile of the lumen (Figure 45).

\section{Histopathology of digestive gland}

When exposed to both subletahal concentrations of oil effluent, produced gross changes in the epithelium of the glands as well as

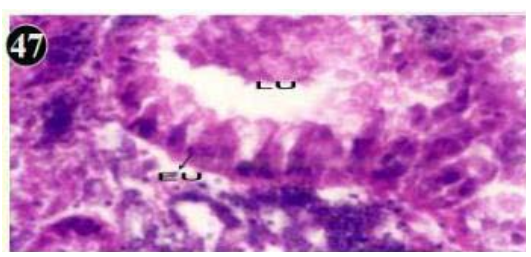

Figure 47: Haematoxylin and eosin stained paraffin sections of treated mussel digestive gland tissue ( $1 / 4^{\text {th }}$ accumulation- $\left.\right|^{\text {st }}, 8^{\text {th }}$ and $15^{\text {th }}$ days $)(X 400)$

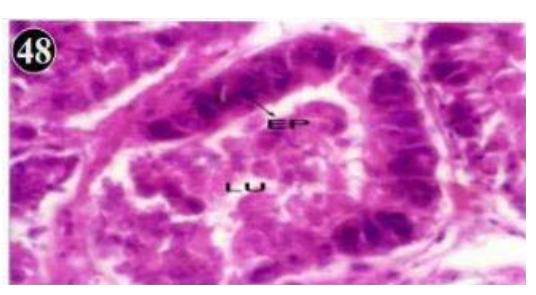

Figure 48: Haematoxylin and eosin stained paraffin sections of treated mussel digestive gland tissue. (1/4 $4^{\text {th }}$ accumulation- $I^{\text {st }}, 8^{\text {th }}$ and $15^{\text {th }}$ days) (X400).

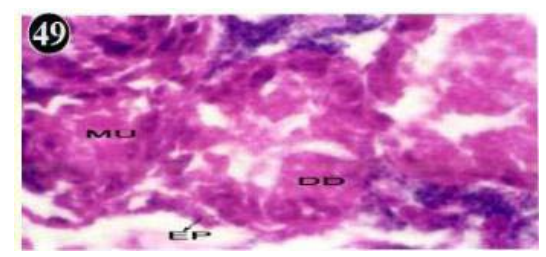

Figure 49: Haematoxylin and eosin stained paraffin sections of treated mussel digestive gland tissue. ( $1 / 4^{\text {th }}$ accumulation-22 $2^{\text {nd }}$ and $30^{\text {th }}$ days) $(X 400)$.

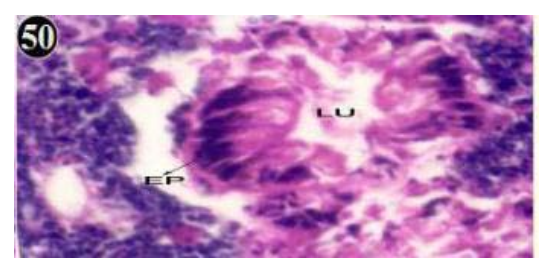

Figure 50: Haematoxylin and eosin stained paraffin sections of treated mussel digestive gland tissue. ( $1 / 4^{\text {th }}$ accumulation- $22^{\text {nd }}$ and $30^{\text {th }}$ days) $(X 400)$.

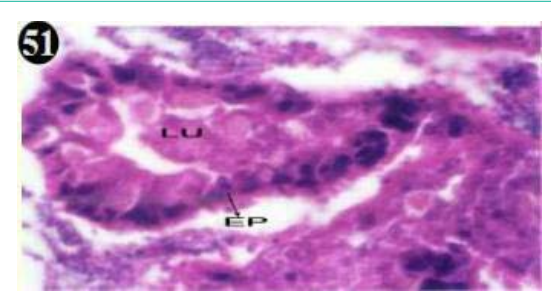

Figure 51: Haematoxylin and eosin stained paraffin sections of treated mussel digestive gland tissue. $\left(1 / 10^{\text {th }}\right.$ accumulation- $\left.\right|^{\text {st }}, 8^{\text {th }}, 15^{\text {th }}$ and $22^{\text {nd }}$ days $)$ (X400).

the stroma. The glandular epithelium was invariably detached from the stroma (Figure 46-65). This stroma adds dense accumulation leucocytes from $\mathrm{I}^{\text {st }}$ day of both sublethal concentrations. The integrity of the epithelium was thoroughly disrupted and a major change was consisted of vertical clefts. Another important feature was noticed towards the dense accumulation of the luminal material, which also 


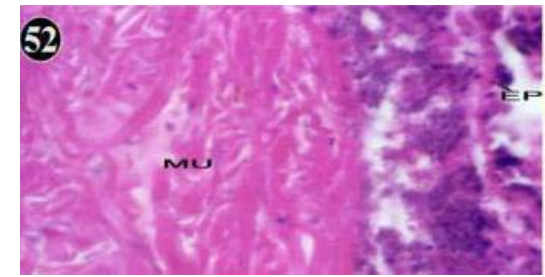

Figure 52: Haematoxylin and eosin stained paraffin sections of treated mussel digestive gland tissue. ( $\left(1 / 10^{\text {th }}\right.$ accumulation- $\left.\right|^{\text {st }}, 8^{\text {th }}, 15^{\text {th }}$ and $22^{\text {nd }}$ days $)$ (X400).

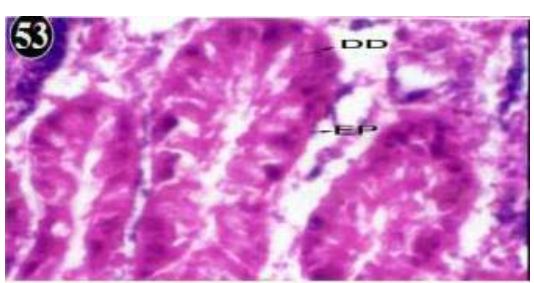

Figure 53: Haematoxylin and eosin stained paraffin sections of treated mussel digestive gland tissue. $\left(1 / 10^{\text {th }}\right.$ accumulation- $\left.\right|^{\text {st }}, 8^{\text {th }}, 15^{\text {th }}$ and $22^{\text {nd }}$ days $)$ (X400).

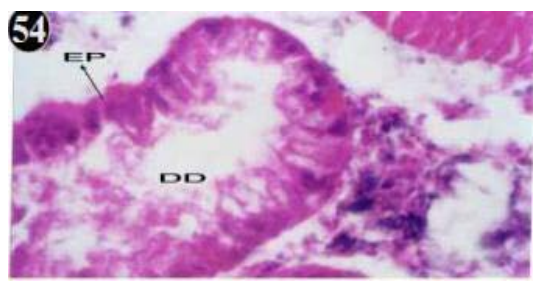

Figure 54: Haematoxylin and eosin stained paraffin sections of treated mussel digestive gland tissue. $\left(1 / 10^{\text {th }}\right.$ accumulation- $I^{\text {st }}, 8^{\text {th }}, 15^{\text {th }}$ and $22^{\text {nd }}$ days $)$ (X400).

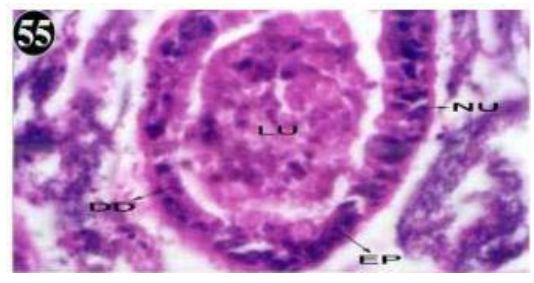

Figure 55: Haematoxylin and eosin stained paraffin sections of treated mussel digestive gland tissues ( $1 / 10^{\text {th }}$ accumulation- $30^{\text {th }}$ days). (X400).

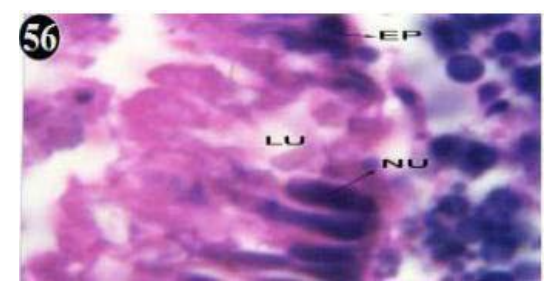

Figure 56: Haematoxylin and eosin stained paraffin sections of treated mussel digestive gland tissue. $\left(1 / 4^{\text {th }}\right.$ accumulation- $\left.\right|^{\text {st }}, 8^{\text {th }}, 15^{\text {th }}, 22^{\text {nd }}$ and $30^{\text {th }}$ days) (X1000).

contain leucocytes, which were otherwise confined to stroma. During the recovery (depuration) period, the fresh water mussel brought

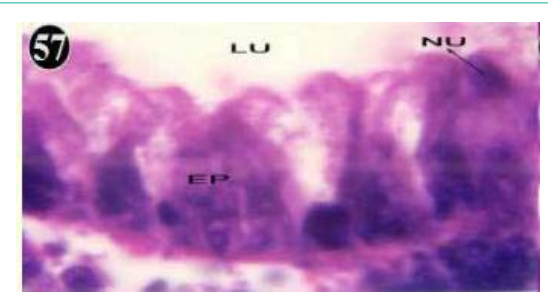

Figure 57: Haematoxylin and eosin stained paraffin sections of treated mussel digestive gland tissue. $\left(1 / 4^{\text {th }}\right.$ accumulation- $\left.\right|^{\text {st }}, 8^{\text {th }}, 15^{\text {th }}, 22^{\text {nd }}$ and $30^{\text {th }}$ days) (X1000).

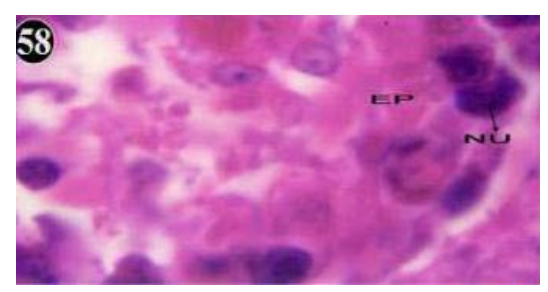

Figure 58: Haematoxylin and eosin stained paraffin sections of treated mussel digestive gland tissue. $\left(1 / 4^{\text {th }}\right.$ accumulation- $\left.\right|^{\text {tt }}, 8^{\text {th }}, 15^{\text {th }}, 22^{\text {nd }}$ and $30^{\text {th }}$ days) (X1000)

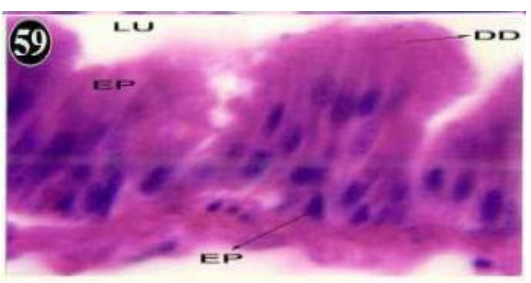

Figure 59: Haematoxylin and eosin stained paraffin sections of treated mussel digestive gland tissue. (1/4 $4^{\text {th }}$ accumulation- $I^{\text {st }}, 8^{\text {th }}, 15^{\text {th }}, 22^{\text {nd }}$ and $30^{\text {th }}$ days) (X1000).

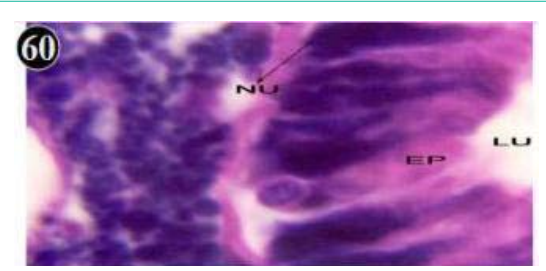

Figure 60: Haematoxylin and eosin stained paraffin sections of treated mussel digestive gland tissue. (1/4 $4^{\text {th }}$ accumulation- $I^{\text {st }}, 8^{\text {th }}, 15^{\text {th }}, 22^{\text {nd }}$ and $30^{\text {th }}$ days) (X1000)

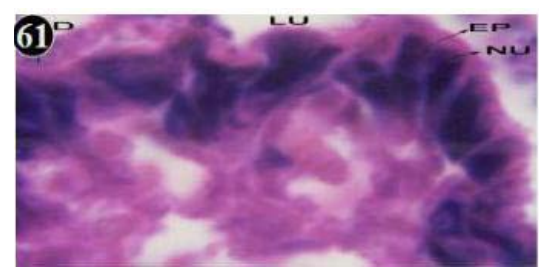

Figure 61: Haematoxylin and eosin stained paraffin sections of treated mussel digestive gland tissue. $\left(1 / 10^{\text {th }}\right.$ accumulation- $-^{\text {st }}, 8^{\text {th }}, 15^{\text {th }}, 22^{\text {nd }}$ and $30^{\text {th }}$ days). (X1000).

about a gradual restoration of the organization of the digestive gland and nature of the epithelium. The day $15^{\text {th }}$ onwards the glandular 


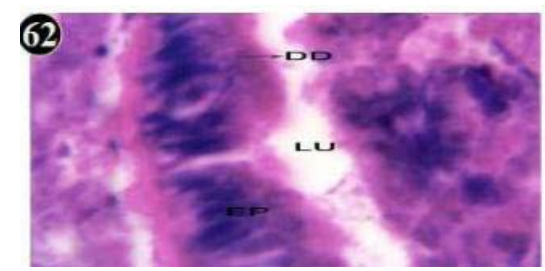

Figure 62: Haematoxylin and eosin stained paraffin sections of treated mussel digestive gland tissue. (1/10 $0^{\text {th }}$ accumulation- $-^{\text {st }}, 8^{\text {th }}, 15^{\text {th }}, 22^{\text {nd }}$ and $30^{\text {th }}$ days). (X1000).

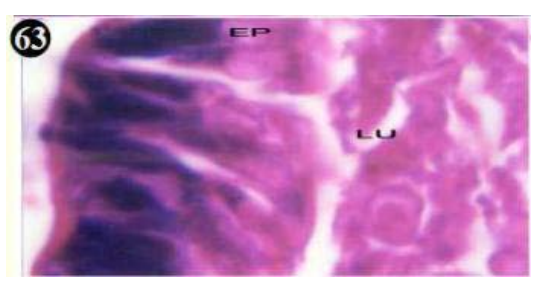

Figure 63: Haematoxylin and eosin stained paraffin sections of treated mussel digestive gland tissue. $\left(1 / 10^{\text {th }}\right.$ accumulation- $\left.\right|^{\text {st }}, 8^{\text {th }}, 15^{\text {th }}, 22^{\text {nd }}$ and $30^{\text {th }}$ days). (X1000).

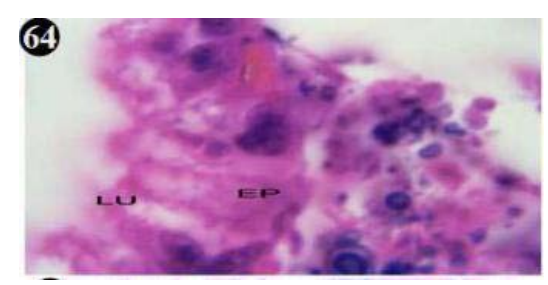

Figure 64: Haematoxylin and eosin stained paraffin sections of treated mussel digestive gland tissue. $\left(1 / 10^{\text {th }}\right.$ accumulation- $-^{\text {st }}, 8^{\text {th }}, 15^{\text {th }}, 22^{\text {nd }}$ and $30^{\text {th }}$ days). (X1000).

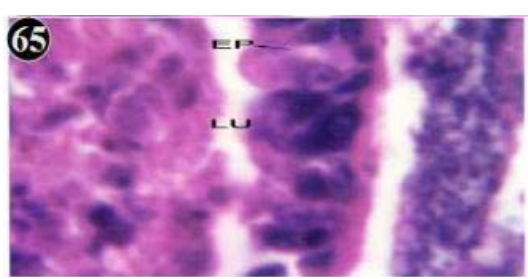

Figure 65: Haematoxylin and eosin stained paraffin sections of treated mussel digestive gland tissue. $\left(1 / 10^{\text {th }}\right.$ accumulation- $\left.\right|^{\text {st }}, 8^{\text {th }}, 15^{\text {th }}, 22^{\text {nd }}$ and $30^{\text {th }}$ days). (X1000).

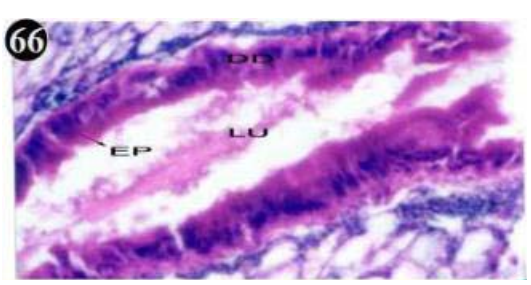

Figure 66: Haematoxylin and eosin stained paraffin sections during depuration period of mussel digestive gland tissue. $\left(1 / 4^{\text {th }}\right.$ depuration- $-^{\text {st }}$ day $)$ (X1000).

architecture was comparable to that of the control mussels, though the dense accumulation of leucocytes between the stroma and

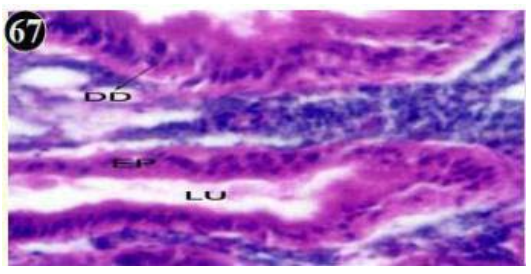

Figure 67: Haematoxylin and eosin stained paraffin sections during depuration period of mussel digestive gland tissue. $\left(1 / 4^{\text {th }}\right.$ depuration- $8^{\text {th }}, 15^{\text {th }}$, $22^{\text {nd }}$ and $30^{\text {th }}$ days; $1 / 10^{\text {th }}$ depuration- $1^{\text {st }}$ and $8^{\text {th }}$ days). (X1000).

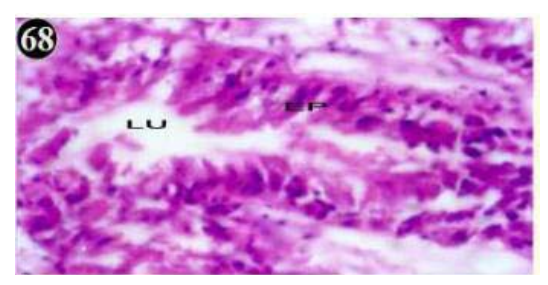

Figure 68: Haematoxylin and eosin stained paraffin sections during depuration period of mussel digestive gland tissue. $\left(1 / 4^{\text {th }}\right.$ depuration- $8^{\text {th }}, 15^{\text {th }}$, $22^{\text {nd }}$ and $30^{\text {th }}$ days; $1 / 10^{\text {th }}$ depuration- $1^{\text {st }}$ and $8^{\text {th }}$ days). (X1000).

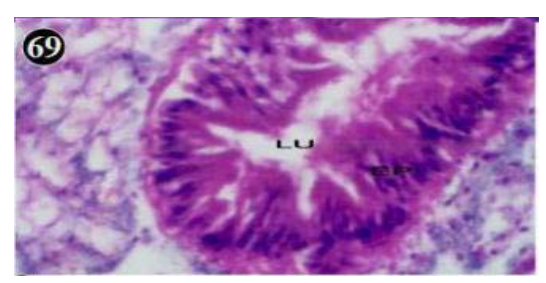

Figure 69: Haematoxylin and eosin stained paraffin sections during depuration period of mussel digestive gland tissue. $\left(1 / 4^{\text {th }}\right.$ depuration- $8^{\text {th }}, 15^{\text {th }}$, $22^{\text {nd }}$ and $30^{\text {th }}$ days; $1 / 10^{\text {th }}$ depuration- $1^{\text {st }}$ and $8^{\text {th }}$ days). (X1000).

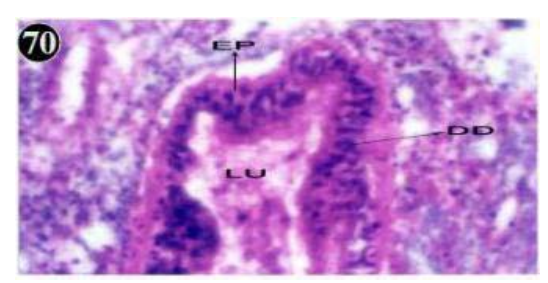

Figure 70: Haematoxylin and eosin stained paraffin sections during depuration period of mussel digestive gland tissue. $\left(1 / 4^{\text {th }}\right.$ depuration- $8^{\text {th }}, 15^{\text {th }}$, $22^{\text {nd }}$ and $30^{\text {th }}$ days; $1 / 10^{\text {th }}$ depuration- $1^{\text {st }}$ and $8^{\text {th }}$ days). (X1000).

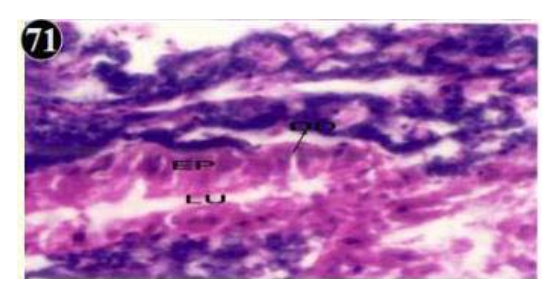

Figure 71: Haematoxylin and eosin stained paraffin sections during depuration period of mussel digestive gland tissue. $\left(1 / 4^{\text {th }}\right.$ depuration- $8^{\text {th }}, 15^{\text {th }}$, $22^{\text {nd }}$ and $30^{\text {th }}$ days; $1 / 10^{\text {th }}$ depuration- $1^{\text {st }}$ and $8^{\text {th }}$ days). (X1000).

epithelium continued till the $30^{\text {th }}$ day, but the stroma was absent i.e. completely restored (Figure 66-75). 


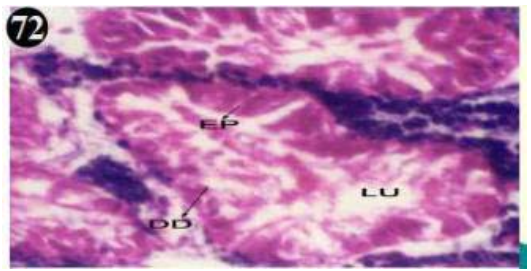

Figure 72: Haematoxylin and eosin stained paraffin sections during depuration period of mussel digestive gland tissue. $\left(1 / 4^{\text {th }}\right.$ depuration- $8^{\text {th }}, 15^{\text {th }}$, $22^{\text {nd }}$ and $30^{\text {th }}$ days; $1 / 10^{\text {th }}$ depuration- $1^{\text {st }}$ and $8^{\text {th }}$ days). (X1000).

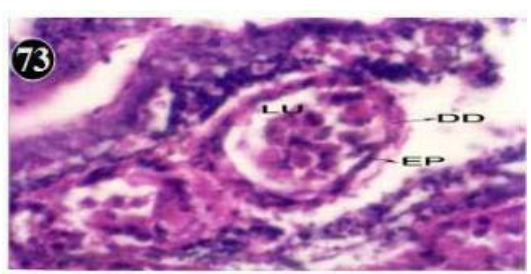

Figure 73: Haematoxylin and eosin stained paraffin sections during depuration period of mussel digestive gland tissue. $\left(1 / 10^{\text {th }}\right.$ depuration- $15^{\text {th }}$ $22^{\text {nd }}$ and $30^{\text {th }}$ days) (X1000).

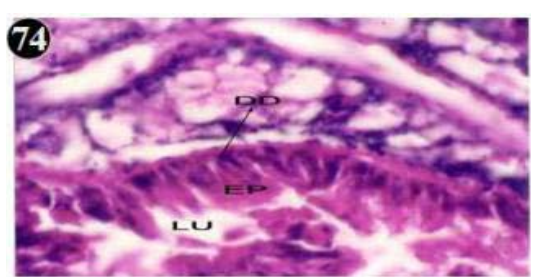

Figure 74: Haematoxylin and eosin stained paraffin sections during depuration period of mussel digestive gland tissue. $\left(1 / 10^{\text {th }}\right.$ depuration- $15^{\text {th }}$ $22^{\text {nd }}$ and $30^{\text {th }}$ days) $(\mathrm{X} 1000)$.

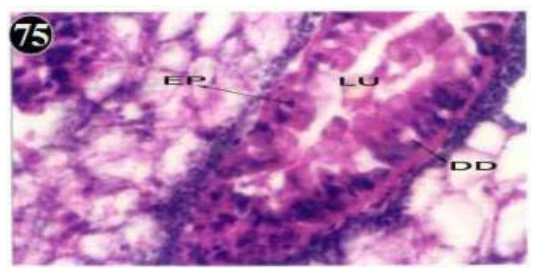

Figure 75: Haematoxylin and eosin stained paraffin sections during depuration period of mussel digestive gland tissue. $\left(1 / 10^{\text {th }}\right.$ depuration- $15^{\text {th }}$ $22^{\text {nd }}$ and $30^{\text {th }}$ days) $(\mathrm{X} 1000)$.

\section{Discussion}

Biological, physiology and morphological structure of molluscan systems were described [20-22]. The normal structure of mussels gill, foot, digestive gland has been well-described [23,24]. In some publications, lesions have only been described morphologically [25]. Summary of some relevant earlier literature on marine as well as freshwater mussels histological observations with various toxicants and comparison with our present results are compiled (Table 1). In the present study, when exposed to both sublethal concentrations of oil effluent little changes were observed in mussels foot tissue on $\mathrm{I}^{\text {st }}$ day. From $8^{\text {th }}$ day onwards, outer epithelium of the mussels' foot tissue were disorgnaised and resulted in necrosis of the cell. When exposed to the sublethal concentrations of oil effluent, for longer duration's muscle bundle themselves were also disorgnaised in mussel foot tissue. This could lead to the failure of a number of biochemical activities as well as osmo and iono-regulatory functions of the foot. Present histopathological findings may explain a defensive reaction from the mussels under investigation as similar results were observed by molluscan researchers. Thus, the present results are in agreement with [26] who exposed to heavy metals splitting of muscle bundles in foot tissue were observed in the fresh water mussel, Lamellidens marginali. Similar findings [27] were observed disruption of nuclei of the epithelial glands in foot tissue when exposed to pesticide. The histopathology of foot indicated that concentration and duration of exposure period resulted in massive destruction in normal architecture of foot tissue of mussel. Similarly, the disruption of the epithelium of the gill filaments and all the versions of the cilia were observed when exposed of both sublethal concentrations of oil effluent. The epithelium indicated severe pathological changes of the oedima formation and necrosis. The cilia appeared disaggregated during accumulation of both sublethal concentrations of oil effluent. The gills (ctenidia) of lamellibranch bivalves play a dominant role in controlling the interaction between the individual and its environment. A great deal of literature is available on the mechanisms of food particle retention, as well as on the nature and activities of the cilary systems of such organs [28]. Histological alterations and biochemical changes of gill tissues produced by the chemical stress causes disturbed metabolism, enzyme inhibition, retardation of growth, fecundity reduction and longevity of the organism, which will affect balance in the ecosystem [29]. An exhaustive review of toxicant/ irritant induced changes in the gill, stated that the inflammatory changes tend to be largely non-specific, and seen to reflect physiological adaptation to stresses were made [16]. Tributyltin (TBT) treated mussel Mytilus galloprovincialis the structure of gill was destroyed, interfilament junctions and cilia disappeared and lateral and endothelial cells were changed [30]. A wide variety of histopathological and physiological responses to naphthalene exposure were described in the mummichog Fundulus heteroclitus [31]. Structural changes and proliferate lesions of gills in Salmo trutta, Oncorhychus mykiss, was observed [32] when exposed to sewage plant effluents. When exposed to pesticides, fusion of gill lamellae in Lamellidens marginalis [33], gill epithelium lining and disruption in Lamellidens marginalis [34], gill exibits reducing space between channels, tissue swelling in Lamellidens marginalis [35], vacuolation, epithelial alterations in Mytilus galloprovincialis [36], damaged epithelium, cilia, epithelium ruptured in gill of Unio pictorum [37], elongated gill filament, gill epithelium ruptured with damaged ciliary lining in Lamellidens marginalis [38] were observed and when exposed to microplastics, epithelial alterations, necrosis were observed in Mytilus spp. [39]. When exposed to heavy metals loss of cilia, epithelial damage, swollen lumen, elongation of gill filaments in Perna viridis [40]; gill filaments altered, oedematic, necrotic and vacuolated epithelium in Lamellidens marginalis [41] were observed. Hence, the changes in the histopathological structure of the gill can be use as biomarkers of exposure in the aquatic environment and the freshwater bivalve Lamellidens marginalis can be considered as a bioindicator organism to assess the water quality. Similarly, the digestive gland produced gross changes in the epithelium of the glands as well as the stroma. The glandular epithelium invariably 
detached from the stroma were observed in mussel, during accumulation period of oil effluent. This stroma adds dense accumulation of leukocytes from $\mathrm{I}^{\text {st }}$ day exposure of both concentrations. Thoroughly disrupted integrity of the epithelium was observed during the accumulation of both sublethal concentrations of oil effluent and a major change was consisted of vertical clefts Another important feature were observed towards the dense accumulation of the luminal material, which also contain leukocytes, which were otherwise confined to stroma. The responses of digestive gland of mussels to various pollutants exposure of previous results and our present study are in agreement with the following findings of works. Disruption in the epithelial of glands, tissue burden, digestive tube thickness, lumen enlargement, necrotic tissues by heavy metals in Mytilus galloprovincialis [42,43], in mytilus edulis [44], in Perna viridis, Perna indica [45,46], in Crenomytilus grayanus [17]; PAH induced altered diverticula, damages in digestive tubules in Mytilus galloprovincialis [47]; industrial effluents alters vacuolar degeneration in Mytilus galloprovincialis [48]; mixture of micro-plastics altered atrophies, lumen enlargement in Mytilus spp [39]; insecticide damages digestive tubule alterations, hypertrophy, hyperplasia in Mytilus galloprovincialis [36]; heavy metals damages hemocytic infiltration digestive gland, inflammation in Anodonta cygnea [49], condensed nuclei, altered morphology of cell in Dreissena polymorpha [50], increase of atrophic tubule, damages lumen of digestive tubule in Mytilus galloprovincialis [51]; anthropogenic contaminant induces diverticula, inter-tubular tissue necrosis in Ruditapes decussatus [52]; xylene, benzene and gear oil-WSF damages cell debris, fusion of nuclei, disintegration of epithelial cells necrosis in Gafrarium divaricatum (calm) [53]; pesticide alters disruption in digestive tubules, epithelial lining, necrotic tissue in the lumen in Lamellidens marginalis [54] were observed. Disruption of normal lysosomal function is indicated by the increased fragility of lysosomes in digestive cells throughout the experiment and this is reflected in a reduced physiological scope for growth [55]. Formation of neoplasams in the digestive gland in Unio pictorum by subjecting 200-400 ppm diethyl- and dimethylnitrosamines were observed [56]. Number of gill mucous cells and the heights of digestive diverticula tubule cells were different, compared with the control, at 2 or 4 weeks, when exposed to cadmium were observed [57]. During depuration (recovery) period, the mussel brought about almost complete restorations of the histo-architecture of the foot tissue. Similarly, brought about partial to almost complete restoration of the histoarchitecture of the gill filaments. The cilia appeared normal. The epithelium is almost free from oedima formation and necrosis. Likewise, the mussel brought about a gradual restoration of the organization of the digestive gland and nature of the epithelium. The day $15^{\text {th }}$ onwards the granular architecture was comparable to that of the control mussels, though the dense accumulation of leukocytes between the stroma and epithelium continued till the $30^{\text {th }}$ day, but the stroma was absent, completely restored. Such a high level of oil effluent toxicity (concentration and duration) in digestive gland might be responsible of histological alterations. The digestive gland is also helpful for metabolism of xenobiotics. The histological damage to digestive gland tissue of Lamellidens marginalis due to exposure of oil effluent, definitely disturbs its normal functions like secretion, absorption and storage of nutrient materials and this gland is also helpful for metabolism of oil effluent. Present histopathology investigation on the freshwater mussel is sparse, to fill up the gap, a preliminary study has been carried out on the mussel Lamellidens marginalis.

\section{Conclusion}

The results of this study are well under the aims and objective of the study. However, results of our research enabled us to understand that histopathological changes in the foot, gill and digestive gland tissues of freshwater mussel, Lamellidens marginalis and is noted accumulator organism of oil pollution. The observed damage to foot, gill and digestive gland tissues due to oil effluent and definitely disturbs its normal functions and storage of nutrient materials. Particularly, the digestive gland is also helpful for metabolism of xenobiotics in freshwater mussel Lamellidens marginalis. These histopathology might be due to the possible utilization for metabolic purpose and may be of early warning signals of environmental pollution.

\section{Acknowledgement}

Authors wish to thank, Department of Animal Science, Bharathidasan University, Tiruchirappalli, Tamilnadu, India, for providing necessary facilities for completion of research work.

\section{References}

1. Cajaraville MP. Towards an integrative approach in environmental contamination and toxicology. The Sci Total Environ. 2000; 247: 95-97.

2. Livingstone DR, Forlin L, George SG. Molecular biomarkers and toxic consequences of impact by organic pollution in aquatic organisms. In Sutcliffe, D.N. (Ed.), Water Quality and Stress Indicators in Marine and Freshwater Systems: Linking Levels of Organization. Freshwater Biological Association, Ambleside. 1994; 154-171.

3. Mathur DS, Agarwal MD, Rane PD. Histopathological changes in liver and intestine of Rana cyanoplyctis induced by aldrin. J Environ Biol. 1981; 2: 105107.

4. Huggett RJ, Kimerle RA, Mehrle PM. In Biomarkers, Biochemical, Physiological, and Histlogical Markers of Anthropogenic Stress. Boca Raton, Florida: Lewis Publishers. 1992.

5. Bowmer CT, Van der Meer M, Scholten MC. A histopathological analysis of wild and transplanted Dreissena polymorpha from the Dutch sector of the River Maas. Comp Bioche Physiol. 1991; 100: 225-229.

6. Balamurugan $S$, Subramanian $P$. Oil effluent toxicity and detoxification mechanism in the freshwater mussel, Lamellidens marginalis. Bharathidasan University, Tiruchirappalli, Tamilnadu. India. 2003.

7. Moore MN, Livingstone DR, Widdows J. Molecular, cellular and physiologica effects of oil-derived hydrocarbons in molluscs and their use in impact assessment. Phil Trans R Soc Lon B.1987; 316: 603-623.

8. Bolognesi C, Rabboni R, Roggieri P. Genotoxicity biomarkers in Mytilus galloprovincialis as indicators of marine pollution. Comp Biochem Physiol. 1996; 113: 319-323.

9. Bernet $\mathrm{D}$, Schmidt $H$, Meier W. Histopathology in fish: proposal for a protocol to assess aquatic pollution. J Fish Dis. 1999; 22: 25-34.

10. Johnson LL, Stehr CM, Olson OP. Chemical contaminants and hepatic lesions in water flounder (Pleuronectus americanus) from the Northeast Coast of the United States. Environ Sci Tech. 1993; 27: 2759-2771.

11. Hughes GM. Measurement of gill area in fishes: Practices and problems. $J$ Mar Biol Assoc UK. 1984; 65: 637-655

12. Haniffa MA, Sundaravadananm S. Effect of distillery effluents on food utilization of fresh water fish, Barbus stigma. Life Sci Adv. 1983; 2: 146.

13. Hemelraad J, Herwig HJ, Van Donselaar EG. Effects of cadmium in fresh water calms II Ultra structural alterations in the renal system of Anodonta 
cygnea. Arch Environ Contam. Toxicol. 1990; 19: 691-698.

14. Baussant T, Sanni S, Jonsson G. Bioaccumulation of ploycyclic aromaic compounds: 1.Bioconcentration in two marine species and in semipermeable devices during chronic exposure to dispersed crude oil. Environ Toxico Chem. 2001; 20: 1175-1184.

15. Sabaliunas D, Lazutka J, Sabaliuniene L. Use of semipermiable membrane devices for studying effects of organic pollutants: Comparision of pesticide uptake by semipermeable membrane devices and mussels. Environ Toxico Chem.1998; 17: 1815-1824

16. Mallatt J. Fish gill structural changes induced by toxicants and other irritants: a statistical review. Canadian J Fish Aquatic Sci.1985; 42: 630-648.

17. Usheva LN, Vaschenko MA, Durkina VB. Histopathology of the Digestive Gland of the Bivalve Mollusk Crenomytilus grayanus (Dunker, 1853) from Southwestern Peter the Great Bay, Sea of Japan. Russian J Mar Biol. 2016; 32: 166-172.

18. National Crop Production Centre (NCPC). NCPC Technical Bulletin No: 1. Basic computer programmes for the study of populations and othe applications (E Benigo Ed.). 1986.

19. Humason GL. Animal Tissues Techniques. San Francisco: Freeman WH and Co. 1979.

20. Johnson LL, Stehr CM, Olson OP, Myers MS, Pierce SM, Wigren CA, et al. Hyman. The Invertebrates: Mollusca I (Vol. VI). McGraw-Hill, New York. 1967.

21. Purchon RD. The biology of mollusca. $2^{\text {nd }}$ edn. Pergamon, Oxford. 1977.

22. Barnes RD. Invertebrate Zoology. WB Saunders Co Phila. 1963; 632.

23. Owen G. Lysosomes, peroxisomes and bivalves. Sci Prog Oxf. 1972; 60: 299-318.

24. Langton RW. Synchrony in the digestive diverticula of the Mytilus edulis L. J Mar Biol Assoc UK. 1975; 55: 221-229.

25. Hinton DE, Lantz RC, Hampton JA. Normal versus abnormal structure: considerations in morphologic responses of teleosts to pollutants. Environ Health Perspect. 1987; 71: 139-146.

26. Venkata Chandrudu M, Radhakrishnaiah K. Effect of Cadmium on the Histology of Hepatopancreas and Foot of the Freshwater Mussel Lamellidens marginalis (Lam.) Nature Environment and Pollution Technology. 2008; 7: 397-402.

27. Teeni Janet Raj TG, Shyla Suganthi A. Toxic effect of Monocrotophos on the Foot of the Freshwater Mussel, Lamellidens marginalis. ISSN 0976-5417. Cross Res. 2015; 6.

28. Morton B. Feeding and digestion in bivalvia. In: The molusca, vol.5, Physiology, Part, 2 PP-65-187.Ed. by Saleuddin, ASM and Wilbur K. London Academic Press.1983.

29. Sole M, Rivera-Ingraham G, Freitas R. The use of carboxylesterases as biomarkers of pesticide exposure in bivalves: A methodological approach. Comparative Biochemistry and Physiology Part C: Toxicology \& Pharmacology. 2018; 212: 18-24.

30. Micic M, Bihari N, Labura Z. Induction of apoptosis in the blue mussel Mytilus galloprovincialis by tri-n-butyltin chloride. Aquat Toxicol. 2001; 55: 61-73.

31. Di Michele L, Taylor MH. Histopathological and physiological response of Fundulus heteroclitus to naphthalene exposure. J Fish Res Bd Canada. 1978; 35: 1060-1066.

32. Schmidt $H$, Bernet $D$, Wahli T. Active biomonitering with brown and rainbow trout in diluted sewage plant effluents. J Fish Biol. 1999; 54: 585-596.

33. Stalin A, Saiyad musthafa M, Amanullah B. Histological alterations in the gills of freshwater mussel Lamellidens marginalis exposed to sub-lethal concentration of an organophosphorus insecticide, chlorpyrifos. Asian Journal of Microbiology, Biotechnology and Environmental Science. 2011 13: $139-142$

34. Kumar S, Pandey RK, Das S. Dimehoate alters respiratory rate and gill histopathology in freshwater mussel lamellidens marginalis (lamarck). J App
Biosci. 2012; 38: 154-158.

35. Krishnendu D, Mitali R, Sajal R. Structural impairment of gill and digestive gland of Lamellidens marginalis exposed to Cypermethrin. J Ani Biol. 2012; 3: $117-126$

36. Stara A, Pagano M, Capillo G. Assessing the effects of neonicotinoid insecticide on the bivalve mollusc Mytilus galloprovincialis. The Sci Total Environt. 2020; 700: 134914.

37. Khudhur SM, Shekha YA. Histopathological and Biochemical Biomarker Response of Mussel, Unio Pictorum, to Carbamate Pesticide Carbaryl: A Laboratory Study. Indian J Ani Res. 2019; B-1157: 1-5.

38. Rane MS, Kolhe BG. Histopathological alterations in gills of freshwater bivalve, Lamellidens marginalis (Lamarck) after acute exposure to Thiamethoxam and Triazophos. Int J Life Sci. 2019; A13: 24-28.

39. Revel M, Lagarde F, Perrein-Ettajani H, Bruneau M, Ackha F, Sussarellu $\mathrm{R}$, et al. Tissue-Specifific Biomarker Responses in the Blue Mussel Mytilus spp. Exposed to a Mixture of Microplastics at Environmentally Relevant Concentrations. Frontiers in Environ. Sci. 2019; 7: 1-14.

40. Bhargavan B. Haematological responses of green mussel Perna viridis (Linnaeus) to heavy metals copper and mercury. Thesis, Cochin University OF Science and Technology, Kochi-682016, India. 2008.

41. Pandey A, Shanthanagouda AH. Devendra Pathak. Histopathological effects in gills of freshwater mussels Lamellidens marginalis exposed to mercury chloride. The Bioscan. 2016; 11: 2277-2280.

42. Soto M, Ireland MP. The contribution of metal/shell-weight index in targettissues to metal body burden in sentinel marine molluscs. 2. Mytilus galloprovincialis. The Sci Total Environ. 1997; 198: 149-160.

43. Domouhtsidou GP, Dimitriadis VK. Ultrastrucural localization on heavy metals $(\mathrm{Hg}, \mathrm{Ag}, \mathrm{Pb}$ and $\mathrm{Cu})$ in gills and digestive gland of mussels, Mytilus galloprovincialis (L). Arch Environ Contam Toxicol. 2000; 38: 472-478.

44. Sheir SK, Handy RG. Tissue injury and cellular immune response to cadmium chloride exposure in the common mussel, Mytilus edulis: Modulation by lipopolysacchararide. Arch Environ Contam Toxicol. 2010: 59: 602-613.

45. Vasanthi LA, Revathi P, Arulvasu C. Biomarkers of metal toxicity and histology of Perna viridis from Ennore estuary, Chennai, south east coast of India Ecotoxicol. Environ Saf. 2012; 84: 92-98.

46. Philip Mathew, Menon NR. Histological aberrations accompanying chronic metal toxicity in the mussel Perna indica. J Mar Biol Ass India. 2005; 47: 144-149.

47. Cappello T, Maisano M, D'Agata A, Natalaotto A, Mauceri A, Fasulo S. Effects of environmental pollution in caged mussels (Mytilus galloprovincialis). Marine Environ Res. 2013; 91: 52-60.

48. Katalay S, Yavasoglu A, Yigittürk G. Histological effects of pollution on gill and hepatopancreas tissues of black mussels (Mytilus galloprovincialis) from izmir bay of turkey. Fresenius. Environ. Bull. 2016; 25: 1460-1466.

49. Khan MI, Khisroon M, Khan A. Bioaccumulation of Heavy Metals in Water, Sediments, and Tissues and Their Histopathological Effects on Anodonta cygnea (Linea, 1876) in Kabul River, Khyber Pakhtunkhwa, Pakistan. Bio Med Research International. 2018; 2018: 1-10.

50. Casellato S, Masiero L, Ballarin L. Toxicity of fluoride to the freshwater mollusc, Dreissena polymorpha: Effects on survival, histology, and antioxidant enzyme activity. Research Report Fluoride. 2012; 45: 35-46.

51. Rocha TL, Morais SMTS, Bebianno MJ. Histopathological assessment and inflammatory response in the digestive gland of marine mussel Mytilus galloprovincialis exposed to cadmium-based quantum dots. Aquatic Toxicol. 2016; 177: 306-315.

52. Pedro M, Carreira S, Maria H. Development of histopathological indices in a commercial marine bivalve (Ruditapes decussatus) to determine environmental quality. Aquatic Toxicol. 2012; 126: 442-454

53. Agwuocha S, Kulkarni BG, Pandey AK. Histopathological alterations in hepatopancreas of Gafrarium divaricatum exposed to xylene, benzene and gear oil-WSF. J Environ Biol. 2011; 32: 35-38. 
54. Kumar S, Pandey RK, Das S. Pathological changes in hepatopancreas of freshwater mussel Lamellidens marginalis (Lamarck) exposed to sub-lethal concentration of Dimethoate. GERF Bull. Biosci. 2011; 2: 18-23.

55. Widdows J, Moore SL, Clarke KR. Uptake, tissue distribution and elimination of $\left[1-{ }^{14} \mathrm{C}\right]$ naphthalene in the mussel Mytilus edulis. Mar Biol. 1983; 76: 109114

56. Khudolei VV, Sirenko OA. Tumor development in the bivalve mollusk Unio pictorum induced by N-nitroso compounds. Bull Expre Biol Med. 1997; 83: 684-686.

57. Giraud AS, Webster LK, Fabris JG. Absence of histopathological responses to cadmium in gill and digestive diverticula of the mussel, Mytilus edulis. Bull Environ Contam Toxicol. 1986; 36: 146-149. 